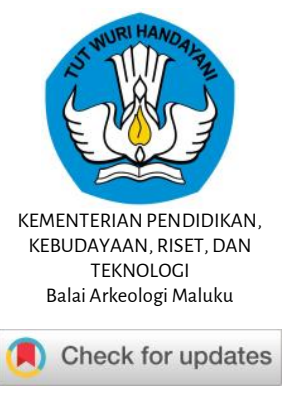

Kapata Arkeologi, 17(1) 2021, 33-42

p-ISSN: 1858-4101, e-ISSN: 2503-0876

KAPATA ARKEOLOGI

SCIENTIFIC Journal of ARCHAEOLOgY AND Cultural STUdies

Accredited by the Indonesian Ministry of Research, Technology, and Higher Education (RISTEKBRIN)
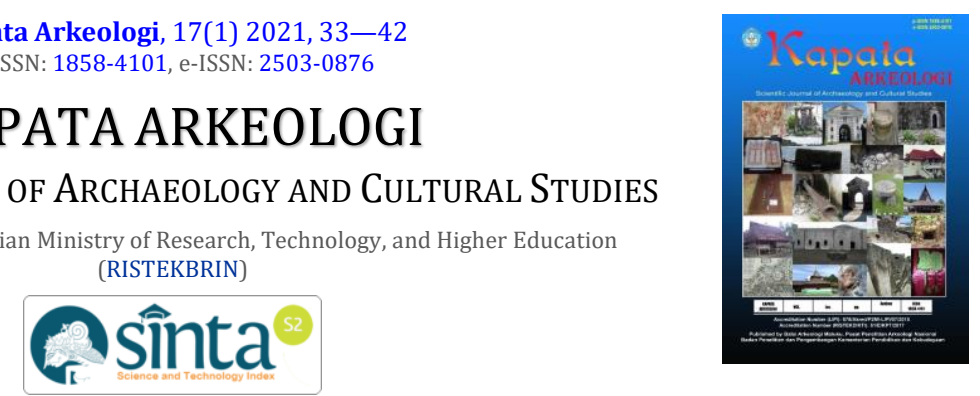

http://kapata-arkeologi.kemdikbud.go.id/

\title{
POSITIVE IDENTIFICATION ON THE SKULl FroM COLONIAL ERA IN Balai Pemuda, Surabaya
}

\author{
Suhendra, Bagaskara Adhinugroho, Yusuf Bilal Abdillah, Biandro Wisnuyana, Ali Akbar \\ Maulana, Bayoghanta Maulana Mahardika, Rizky Nur Andrian, Rizky Sugianto Putri, Delta Bayu \\ Murti, Toetik Koesbardiati (D) * \\ Universitas Airlangga \\ J1. Airlangga 4-6 Kecamatan Gubeng, Surabaya 60115, Indonesia \\ *toetik.koesbardiati@gmail.com
}

Received: 14/06/2019; revisions: 12/11/2019 — 23/11/2020; accepted: 10/12/2020

\begin{abstract}
Two human skulls were found during basement construction from November $30^{\text {th }}, 2016$, to December $1^{\text {st }}$, 2016, in Balai Pemuda, Surabaya, one of Indonesia's colonial-era buildings. The discovery of two skulls raised questions, such as the identity and its context of existence. Both skulls were coded as skull 160689 and 160690. This research aimed to reveal the identity of skull 160689 and 160690 based on the positive identification procedure of forensic anthropology. This research applies the method of the forensic anthropology identification procedure. This method was used sequentially, firstly age, secondly gender, thirdly population affiliation, fourthly stature, and lastly, individual characteristics. Interestingly, the individual characteristics of skull 160690 have distinct evidence for explaining its identity, for instance, dental modification, disease markers, and asymmetrical head shape. Based on the positive identification results on skull 160689 and 160690 showed both skulls were female and affiliated with Mongoloid population. At last, individual characteristics and deformation on the occipital area were indicated as an unintentional deformation caused by pressure continuously on the left side of the occipital area. Plagiocephaly could be a result of incorrect sleeping position during childhood.
\end{abstract}

Keywords: Positive Identification; skull; Forensic Anthropology; Colonial Era; Surabaya

\section{INTRODUCTION}

Balai Pemuda is one of the buildings which noted many vital events during Dutch and Japanese colonization in Surabaya, Jawa Timur Province, Indonesia. The original name of Balai Pemuda was De Simpangsche Societeit, designed in 1907 by Dutch architect, Westmaas. Balai Pemuda functioned as an entertainment building for the European elites who lived in Surabaya. De Simpangsche Societeit was located in the city centre of Surabaya between the main road of Simpangschestraat (Pemuda Street), Palmenlaan (Panglima Sudirman Street), and Dijkermanstraat (Yos Sudarso Street). There was a rule that stated that indigenous and middle-east people were not allowed to enter the building due to political policy created by the Dutch (Riyanto, 2000). After the Japanese successfully colonized Surabaya, Balai Pemuda still functioned as an entertainment building. In that era, the indigenous were allowed to enter the building only as entertainers. In fact, this policy changed the image of De Simpangsche
Societeit building as a brothel or prostitution area that was legalized by the government for the first time (Pratama, 2010). Widodo states (In Soedarso, Nurif, Sutikno, \& Windiani, 2013) that there was a bunker to torture the Dutch during battles, and it was used to store corpses.

Balai Pemuda building is registered as National Cultural Heritage Number CB.648 (Ditjen Kebudayaan Kemdikbud, 2019). The building faces north and is surrounded by an iron fence with a door on the east. The north gate is opened on certain occasions. There are small dome-shaped walls on the sidelines of the fence equipped with lanterns. On the west side, there are plants and shade trees. The building is painted white with high arched doors and windows above it. The floor is made of ceramic. At the top main entrance, there is a domeshaped crown tower decorated with blue ice glass as an air vent to absorb sunlight. The front porch has a tin roof with iron pillars, on the left and right of the building is equipped with a terrace/gallery around to protect the sun 
and rainwater. Above the terrace, there are chandeliers. The building consists of rooms with room dividers given wooden/plywood insulation to make it easier to change the room as needed. There are golden flower vines on the walls and a large vanity mirror with marble as decoration.

Two human skulls were found during basement construction at Balai Pemuda. According to detiknews.com (Effendi, 2016), the first skull was found on Wednesday, November $30^{\text {th }}, 2016$, at $10 \mathrm{pm}$ local time, while the second skull was found the next day on Thursday, December $1^{\text {st }}, 2016$, at 9.30 pm local time. There was \pm 3 meters distance between skulls, with 5-7 meters of depth from the surface. The workers and local police conducted further discovery. Eventually, they did not find another part of the body because the crime scene area was already cemented, and it was impossible to dismantle. The analysis of positive identification has never been made on both skulls' although the skull's discovery constructed many questions among the society. This research aimed to reveal the identity of both skulls based on the positive identification procedures of forensic anthropology.

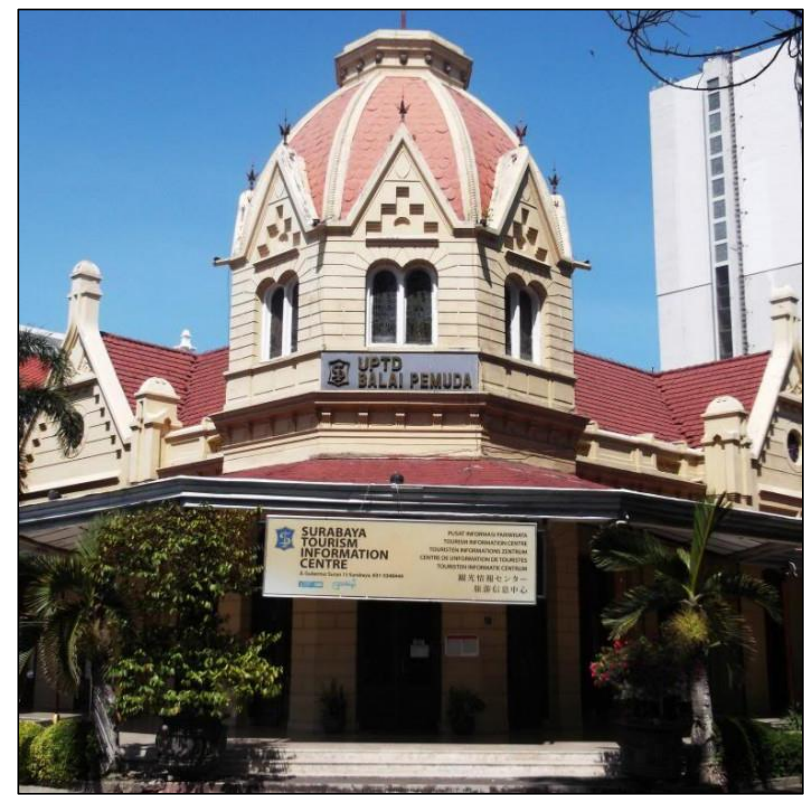

Figure 1. Balai Pemuda building

(Source: Ditjen Kebudayaan Kemdikbud, 2019)

\section{METHODS}

The research objects were curated at Museum Etnografi, Universitas Airlangga, Surabaya, Indonesia. Both skulls were coded as skull 160689 and 160690. Several parts of skulls were destructed. The conditions of both skulls are shown in Table 1.

Table 1. The skulls recovered conditions

\begin{tabular}{lll}
\hline Part of Skull & $\mathbf{1 6 0 6 8 9}$ & $\mathbf{1 6 0 6 9 0}$ \\
\hline Frontal & Present & $\begin{array}{l}\text { Present and } \\
\text { complete }\end{array}$ \\
\multirow{2}{*}{ Nasal } & $\begin{array}{l}\text { Present and } \\
\text { complete }\end{array}$ & $\begin{array}{l}\text { Present and } \\
\text { complete }\end{array}$ \\
\hline
\end{tabular}

\begin{tabular}{|c|c|c|}
\hline Part of Skull & 160689 & 160690 \\
\hline Lacrimal & - & $\begin{array}{l}\text { Present and } \\
\text { complete }\end{array}$ \\
\hline Maxilla & $\begin{array}{l}\text { Present (fractures } \\
\text { only on the left } \\
\text { side) }\end{array}$ & $\begin{array}{l}\text { Present and } \\
\text { complete }\end{array}$ \\
\hline Mandible & - & - \\
\hline Zygomatic bone & $\begin{array}{l}\text { Present (left side } \\
\text { only) }\end{array}$ & $\begin{array}{l}\text { Present (fractures } \\
\text { only on the right } \\
\text { side) }\end{array}$ \\
\hline Zygomatic arch & $\begin{array}{l}\text { Present (left side } \\
\text { only) }\end{array}$ & $\begin{array}{l}\text { Present. 1/2 (left } \\
\text { side) }\end{array}$ \\
\hline \multicolumn{3}{|l|}{ Upper Teeth } \\
\hline Incisors & - & $\begin{array}{l}\text { Present. } 3 / 4 \\
\text { (UI1R missing) }\end{array}$ \\
\hline Canines & - & $\begin{array}{l}\text { Present and } \\
\text { complete }\end{array}$ \\
\hline Premolar & - & $\begin{array}{l}\text { Present and } \\
\text { complete }\end{array}$ \\
\hline Molar & - & $\begin{array}{l}\text { Present. 5/6 } \\
\text { (UM3L missing) }\end{array}$ \\
\hline Parietal bone & $\begin{array}{l}\text { Present and } \\
\text { complete }\end{array}$ & $\begin{array}{l}\text { Present (Right } \\
\text { side only and } \\
\text { partially cracked }\end{array}$ \\
\hline Temporal bone & $\begin{array}{l}\text { Present and } \\
\text { complete (slightly } \\
\text { cracked) }\end{array}$ & $\begin{array}{l}\text { Present (Both } \\
\text { cracked) }\end{array}$ \\
\hline $\begin{array}{l}\text { Interparietal } \\
\text { bone }\end{array}$ & - & Present \\
\hline Wormian bone & - & - \\
\hline Occipital bone & Present & - \\
\hline Sphenoid bone & Present and loose & $\begin{array}{l}\text { Present and } \\
\text { complete }\end{array}$ \\
\hline Palatine bone & - & $\begin{array}{l}\text { Present and } \\
\text { complete }\end{array}$ \\
\hline
\end{tabular}

Byers (2010) procedure was used as positive identification protocol. The aim of this research was to identify age, sex, population affiliation, stature, and personal characteristics as an additional information for skull 160698 and 160690 in Balai Pemuda building.

To estimate the age of skulls' 160689 and 160690 , the scoring methods was applied on the obliteration point of lateral-anterior sutures which consists of midcoronal, pterion, sphenofrontal, inferior sphenotemporal and superior sphenotemporal by Meindl \& Lovejoy (1985). The suture obliteration was divided in four groups:

1) 0: no closure of suture (open)

2) 1: some closure has occurred up to $50 \%$ (minimal closure)

3) 2: there is marked evidence of closure but not completely fused (significant closure)

4) 3: completely fused

The result was added up and adjusted with the technique of age estimation by Buikstra \& Ubelaker (1994) (shown in Table 2).

Table 2. Age estimation based on the lateral-anterior of skull

\begin{tabular}{ccc}
\hline Total score & Stage & Age estimation \\
\hline 1 & S1 & $20-40$ \\
\hline
\end{tabular}




\begin{tabular}{ccc}
\hline Total score & Stage & Age estimation \\
\hline $\mathbf{2}$ & S2 & $30-45$ \\
$\mathbf{3 - 5}$ & S3 & $27-53$ \\
$\mathbf{6}$ & S4 & $30-54$ \\
$\mathbf{7 - 8}$ & S5 & $35-55$ \\
$\mathbf{9 - 1 0}$ & S6 & $40-60$ \\
$\mathbf{1 1 - 1 4}$ & S7 & $48-60$ \\
\hline
\end{tabular}

Source: Buikstra \& Ubelaker (1994)

The age estimation completed by performing nonmetric observation on several characteristics such as skull size, mastoid, browridge, frontal, nuchal area, supraorbital margin and chin (see Table 3). Buikstra \& Ubelaker (1994) divided the characteristics determination into five categories; (1) female, (2) probable female, (3) indeterminate, (4) probable male, and (5) male.

Table 3. Male and female characterizations

\begin{tabular}{lll}
\hline Characteristics & Males & Females \\
\hline Size & $\begin{array}{l}\text { Large and } \\
\text { rugged } \\
\text { Large and } \\
\text { projecting }\end{array}$ & $\begin{array}{l}\text { Small and } \\
\text { smooth }\end{array}$ \\
Brow ridges & Large & $\begin{array}{l}\text { Small and not } \\
\text { projecting } \\
\text { Small and } \\
\text { sometimes not } \\
\text { present } \\
\text { High and } \\
\text { rounded }\end{array}$ \\
Frontal & Slanted & $\begin{array}{l}\text { Smooth and } \\
\text { uncommon hook }\end{array}$ \\
Nuchal area & $\begin{array}{l}\text { Rugged with } \\
\text { hook } \\
\text { (protuberance) }\end{array}$ & Sharp \\
\hline $\begin{array}{l}\text { Supraorbital } \\
\text { margin }\end{array}$ & Rounded & Pointed \\
\hline Chin & Broad & \\
\hline
\end{tabular}

Source: Byers (2010)

The population affiliation is divided in three ancestral groups as mentioned by Byers (2010) and Koesbardiati, Murti, \& Putri (2018). Those three ancestral groups are Caucasoid, Negroid and Mongoloid (see Table 4). To determine the population affiliation, non-metric observation was applied on several parts of the skull. Non-metric observation was beneficial to compare characteristics of three ancestral groups (Caucasoid, Negroid, Mongoloid) which based on literature or another skull.

Table 4. Characteristic of three ancestral group

\begin{tabular}{cccc}
\hline Characteristics & Caucasoid & Mongoloid & Negroid \\
\hline Incisors & Blade-shaped & $\begin{array}{c}\text { Shovel- } \\
\text { shaped }\end{array}$ & $\begin{array}{c}\text { Blade- } \\
\text { shaped }\end{array}$ \\
Molar & $\begin{array}{c}\text { Carabelli's } \\
\text { cusp }\end{array}$ & 4 cusps & 4 cusps \\
Dental density & $\begin{array}{c}\text { Crowded due } \\
\text { to the }\end{array}$ & Not tight & Not tight \\
\hline
\end{tabular}

\begin{tabular}{|c|c|c|c|}
\hline Characteristics & Caucasoid & Mongoloid & Negroid \\
\hline & $\begin{array}{c}\text { presence of } \\
\text { M3 }\end{array}$ & & \\
\hline Face profile & Orthognatic & $\begin{array}{c}\text { Alveolar } \\
\text { Prognathism }\end{array}$ & $\begin{array}{c}\text { Prognathis } \\
\mathrm{m}\end{array}$ \\
\hline Brow ridges & Present & Small & Kecil (?) \\
\hline Muscle marks & Rugged & Smooth & Smooth \\
\hline Post bregma & Straight & Straight & Depressed \\
\hline $\begin{array}{l}\text { Lower eye } \\
\text { border }\end{array}$ & Receding & Projecting & Receding \\
\hline Palatal shape & Parabolic & ellipse & U-shaped \\
\hline Palatal suture & Not straight & Straight & Not straight \\
\hline Cranial suture & Simple & Complex & Simple \\
\hline Nasal aperture & Big and long & Intermediate & Wide \\
\hline Nasal spine & $\begin{array}{l}\text { Square and } \\
\text { indented }\end{array}$ & Intermediate & - \\
\hline Nasal root & $\begin{array}{l}\text { High and } \\
\text { narrow }\end{array}$ & $\begin{array}{l}\text { Low and } \\
\text { projecting }\end{array}$ & $\begin{array}{l}\text { Low and } \\
\text { rounded }\end{array}$ \\
\hline Nasal bridge & High & Low & Low \\
\hline Chin & $\begin{array}{l}\text { Square and } \\
\text { indented }\end{array}$ & Rounded & $\begin{array}{c}\text { Not } \\
\text { indented }\end{array}$ \\
\hline Cranium shape & High & $\begin{array}{l}\text { Low and } \\
\text { tilted }\end{array}$ & $\begin{array}{l}\text { Low with } \\
\text { bent post- } \\
\text { bregma }\end{array}$ \\
\hline Orbital shape & Rounded & Rounded & Square \\
\hline $\begin{array}{c}\text { Wormian } \\
\text { bones }\end{array}$ & 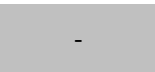 & Present & - \\
\hline $\begin{array}{l}\text { Zygomaticomax } \\
\text { illary suture }\end{array}$ & Curved & $\begin{array}{l}\text { Rectangle- } \\
\text { shaped }\end{array}$ & Curved \\
\hline Inion hook & Present & - & - \\
\hline
\end{tabular}

Source: Byers (2010); Koesbardiati et al. (2018)

Stature estimation was determined from the cephalofacial index by Krishan \& Kumar (2007). The study of Anthropometry measurements was applied to this research. Thus, both skulls were positioned in Frankfurt's plane. The stature estimation was focused on 6 out of 16 points of cephalo-facial measurement had been considered, which were:

1) Maximum head length (g-op). Quantifying the straight distance from glabella $(\mathrm{g})$ to opisthocranion (op).

2) Maximum head breadth (eu-eu). Measuring the most lateral point of the skull that is obtained from euryon.

3) Horizontal circumference of head (g-op-g). Measurement on the glabella point to glabella ( $\mathrm{g}$ ) through opisthocranion (op).

4) Nasal height (n-ns). Distance between nasion to nasiospinale.

5) Morphological superior facial length (n-pr). Measuring the straight distance nasion to prosthion.

6) Nasal breadth (al-al). Measuring between the most lateral point on the margin of the anterior nasal aperture (alare).

The results were counted based on the regression formula (Krishan \& Kumar, 2007) (see Table 5).

Table 5. The regression equation of the stature estimation

\begin{tabular}{ccc}
\hline Index & $\begin{array}{c}\text { Standard } \\
\text { Error }\end{array}$ & Formula \\
\hline $\begin{array}{c}\text { Maximum head } \\
\text { length (g-op) }\end{array}$ & $\pm 4,66$ & $60,961+5,628 . \mathrm{mhl}$ \\
\hline
\end{tabular}




\begin{tabular}{ccc}
\hline Index & $\begin{array}{c}\text { Standard } \\
\text { Error }\end{array}$ & Formula \\
\hline $\begin{array}{c}\text { Maximum head } \\
\text { breadth (eu-eu) } \\
\text { Horizontal } \\
\text { circumference of } \\
\text { head (g-op-g) }\end{array}$ & $\pm 4,71$ & $65,620+6,527 . \mathrm{mhb}$ \\
$\begin{array}{c}\text { Nasal height (n-ns) } \\
\text { Morphological } \\
\text { superior facial } \\
\text { length (n-pr) }\end{array}$ & $\pm 7,01$ & $113,202+8,371 . \mathrm{nh}$ \\
$\begin{array}{c}\text { Nasal breadth } \\
\text { (apt-apt) }\end{array}$ & $\pm 6,31$ & $113,996+6,186 . \mathrm{msfl}$ \\
\hline
\end{tabular}

Source: Krishan \& Kumar (2007)

The individualization was completed by matching particular characteristics from post mortem data (Byers, 2010). Individualization on unknown skull could explain the condition during lifetime. Post mortem data that could be used to identified individualization are scar, trauma, diseases up to cultural activities (Koesbardiati \& Murti, 2016).

\section{RESULT AND DISCUSSION}

\section{Age}

The age estimation result of skulls' 160689 and 160690 based on the 5 ectocranial points were 9 and 2 after being added up (see Table 6). The scoring result was determined based on the shape of suture obliteration (mentioned in method). On the skull 160689, the mid-
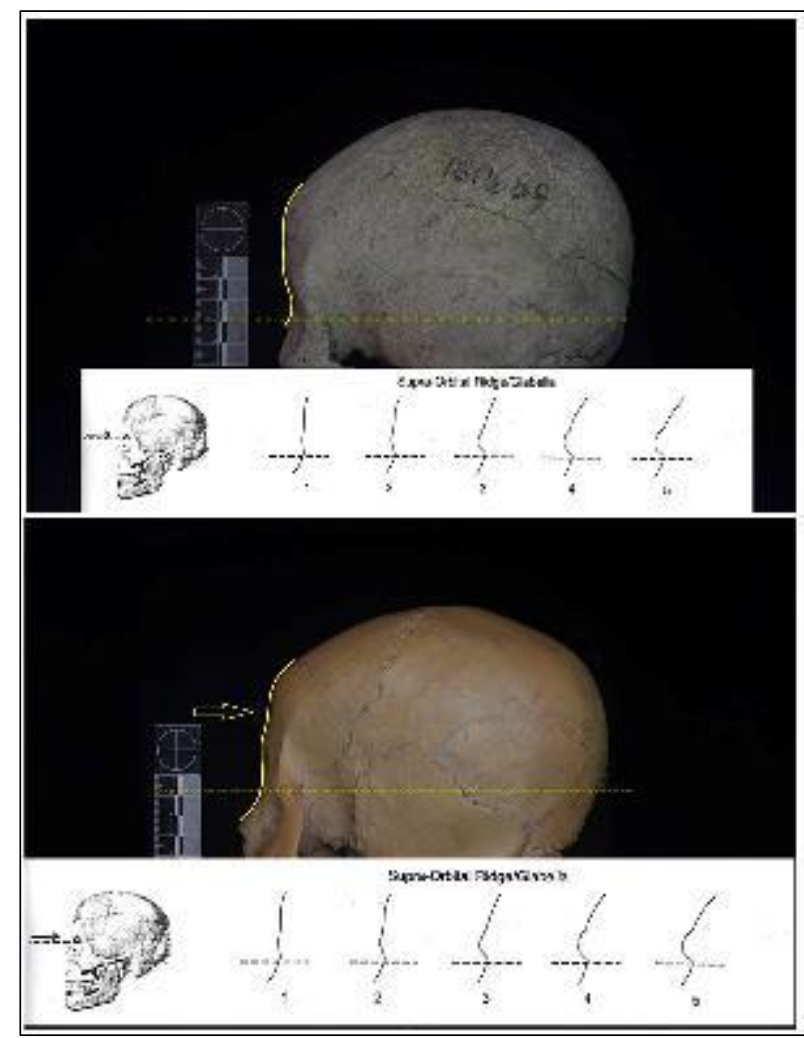

Figure 2. Supra-Orbital Ridge Glabella of skull 160689 (upper) and 160690 (lower)-min
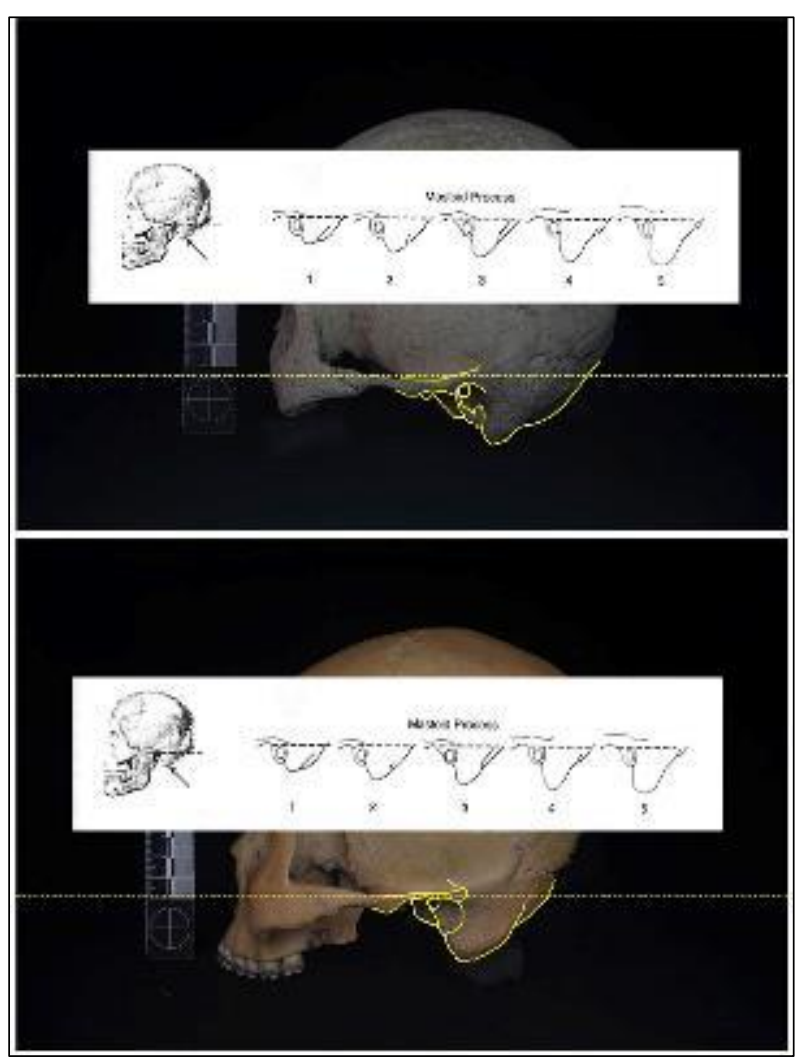

Figure 3. Mastoid Process of skull 160689 (upper) and 16090 (lower)-min

coronal point and pterion had experienced closure but some of it were not completely fused. On the other hand, sphenofrontal, sphenotemporal inferior and sphenotemporal superior indicated vague closure shape. On the contrary, skull 160690 did not show any closure on midcoronal suture, pterion and sphenotemporal superior. However, the sphenofrontal and sphenotemporal inferior had shown vague closure shape.

Table 6. The result of estimated age scoring on the ectocranium

\begin{tabular}{rccc}
\hline \multirow{2}{*}{ No } & Points & $\mathbf{2}$ Scoring \\
\cline { 3 - 4 } 1. & Midcoronal & 2 & $\mathbf{1 6 0 6 9 9}$ \\
2. & Pterion & 2 & 0 \\
3. & Sphenofrontal & 1 & 0 \\
4. & Sphenotemporal & 1 & 1 \\
5. Inferior & Sphenotemporal & 1 & 0 \\
& Superior & $\mathbf{9}$ & $\mathbf{2}$ \\
\hline
\end{tabular}

For most parts of all measurement on lateral-anterior suture were added up, it leads skull 160689 was between 35-45 years old and 26-36 years old respectively, for skull 160690. The result was shown appeared in Table 7.

Table 7. Stature estimation through cephalo-facial index measurement (on mm) of two skulls

\begin{tabular}{ccc}
\hline & 160689 & 160690 \\
\hline Total score & 9 & 2 \\
\hline
\end{tabular}




\begin{tabular}{ccc}
\hline & 160689 & 160690 \\
\hline $\begin{array}{c}\text { Estimated age categorization } \\
\text { according to Ubelaker \& } \\
\text { Buikstra (1994) }\end{array}$ & $\mathrm{S} 5$ & $\mathrm{~S} 2$ \\
Estimated age & $\begin{array}{c}\mathbf{3 5 - 4 5} \\
\text { years old }\end{array}$ & $\begin{array}{c}\mathbf{2 6 - 3 6} \\
\text { years old }\end{array}$ \\
\hline
\end{tabular}
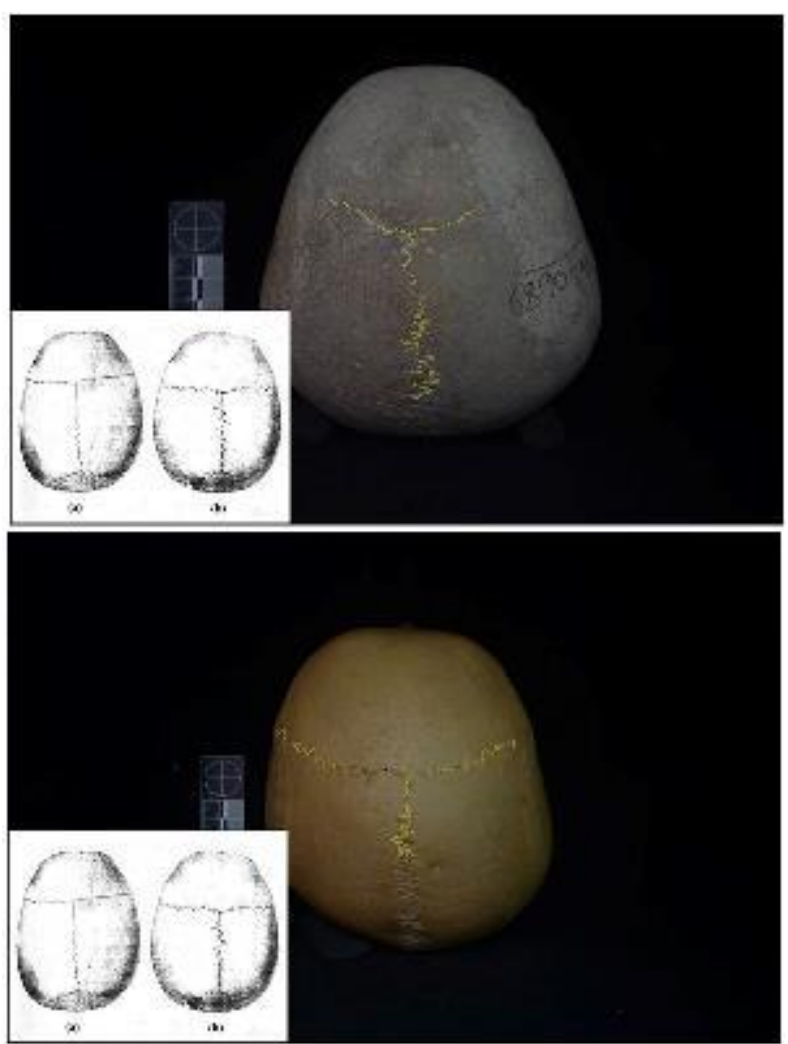

Figure 4. Complexity of cranial vault sutures of skull 160689 (upper) and 160690 (lower)-min

\section{Sex}

Macro observation was conducted based on the sex determinants showed that skull 160689 had smaller and thinner browridge, in different manner, skull 160690 had larger size and smoother texture with faintly non-existent browridge. Another observation on smother supraorbital ridge/glabella indicated skull 160689 could be classified as category 1 while skull 160690 as category 2 (see Figure 2).

This was similar to observation was conducted on the mastoid part which showed that skull 160689 was classified as category 1 and skull 160690 was classified as category 2 (see Figure 3 ). Overall, results of sex determination characteristic are shown on Table 8.

Table 8. Sex determination characteristics of two skulls

\begin{tabular}{lll}
\hline Characteristics & Skull 160689 & Skull 160690 \\
\hline Skull size & Small & $\begin{array}{l}\text { Bigger and } \\
\text { smooth }\end{array}$ \\
Mastoid & Small (1) & $\begin{array}{l}\text { Small and not } \\
\text { projecting (2) }\end{array}$ \\
Brow ridges & $\begin{array}{l}\text { Small and not } \\
\text { projecting }\end{array}$ & Very small \\
\hline
\end{tabular}

\begin{tabular}{lll}
\hline Characteristics & Skull 160689 & Skull 160690 \\
\hline Supra-Orbital & High and & High and \\
Ridge/Glabella & rounded (1) & rounded (2) \\
Nuchal area & Smooth with & - \\
Supraorbital & uncommon hook & - \\
Chin & Sharp (1) & Sharp (2) \\
\hline
\end{tabular}

Based on the observation result, skull 160689 showed female characteristics, such as small size of vault, non-prominent surface of browridges and other characteristics (see Table 9) were categorized in category 1. Skull 160690 shows several characteristics which tend to female, although it had bigger size than skull 160690. Skull 160690 also had non-prominent browridges which was one of the characteristics of female. The complete data was shown in Table 9.

Table 9. Result of sex identification

\begin{tabular}{|c|c|c|c|c|}
\hline Characteristics & $\begin{array}{c}\text { Skull } \\
160689\end{array}$ & $\begin{array}{c}\text { Indication } \\
160689\end{array}$ & $\begin{array}{c}\text { Skull } \\
160690\end{array}$ & $\begin{array}{c}\text { Indication } \\
160690\end{array}$ \\
\hline Size & Small & Female & $\begin{array}{l}\text { Bigger and } \\
\text { smooth }\end{array}$ & $\begin{array}{l}\text { Probable } \\
\text { female }\end{array}$ \\
\hline Mastoid & Small & $\begin{array}{l}\text { Female } \\
\text { (1) }\end{array}$ & $\begin{array}{l}\text { Small and } \\
\text { not } \\
\text { prominent }\end{array}$ & $\begin{array}{l}\text { Probable } \\
\text { female (2) }\end{array}$ \\
\hline Browridges & $\begin{array}{l}\text { Small and } \\
\text { not } \\
\text { prominent }\end{array}$ & Female & - & Female \\
\hline Frontal & $\begin{array}{l}\text { High and } \\
\text { rounded }\end{array}$ & $\begin{array}{l}\text { Female } \\
\text { (1) }\end{array}$ & $\begin{array}{l}\text { High and } \\
\text { rounded }\end{array}$ & $\begin{array}{c}\text { Probable } \\
\text { female (2) }\end{array}$ \\
\hline Nuchal Area & $\begin{array}{l}\text { Smoth with } \\
\text { uncommon } \\
\text { hook }\end{array}$ & $\begin{array}{l}\text { Female } \\
\text { (1) }\end{array}$ & - & - \\
\hline $\begin{array}{c}\text { Supraorbita } \\
\text { margin }\end{array}$ & Sharp & $\begin{array}{l}\text { Female } \\
\text { (1) }\end{array}$ & $\begin{array}{c}\text { Somewhat } \\
\text { sharp }\end{array}$ & $\begin{array}{c}\text { Probable } \\
\text { female (2) }\end{array}$ \\
\hline Chin & - & - & - & - \\
\hline Conclusion & \multicolumn{2}{|c|}{ Female } & \multicolumn{2}{|c|}{ Female } \\
\hline
\end{tabular}

\section{Population affiliation}

The observation result acknowledge/enlighten skull 160689 and 160690 had some variation. The most visible similarity, which constructed in the cranial sutures was classified as type B (see Figure 4).

Contrarily, one of the differences was found in orbital where skull 160689 had similarity with type B and skull 160690 had similarity with type A (see Figure 5).

The full observation results of population affiliation determination are shown in Table 10.

Table 10. Population affiliation characteristics of two skulls

\begin{tabular}{|c|c|c|}
\hline Characteristics & $\begin{array}{c}\text { Skull } \\
160689\end{array}$ & Skull 160690 \\
\hline Incisors & - & Shovel-shaped \\
\hline Molars & - & 4 cusps \\
\hline Density & - & No crowding \\
\hline Face profile & - & - \\
\hline Brow ridges & Small & $\begin{array}{c}\text { Small, almost } \\
\text { not present }\end{array}$ \\
\hline Muscle marks & Smooth & Smooth \\
\hline Post bregma & Straight & $\begin{array}{c}\text { Slightly } \\
\text { depressed }\end{array}$ \\
\hline Lower eye border & Projecting & Projecting \\
\hline
\end{tabular}




\begin{tabular}{ccc}
\hline Characteristics & $\begin{array}{c}\text { Skull } \\
160689\end{array}$ & Skull 160690 \\
\hline Palatal shape & - & Ellipse \\
\hline Palatal suture & - & Straight \\
Cranial suture & Complex & Complex \\
Nasal aperture & - & Intermediate \\
Nasal spine & - & Small \\
Nasal root & Low & Low and \\
projecting
\end{tabular}
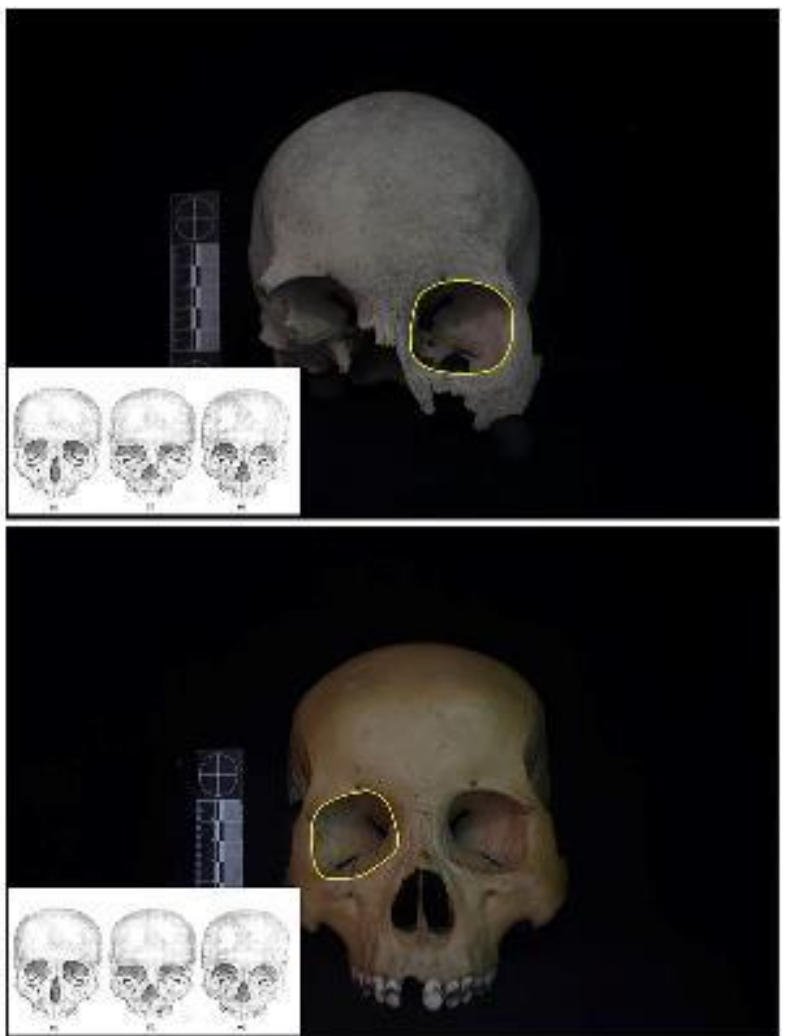

Figure 5. Shapes of eye orbits of skull 160689 (upper) and 160690 (lower)-min

Among to three ancestral groups, the characteristics of skull 160689 and 160690 showed similarities with Mongoloid group. The number of countable similarities was shown in Table 11.

Table 11. The similarities of characteristics of two skulls with Mongoloid population

\begin{tabular}{ccc}
\hline Characteristics of Mongoloid & $\begin{array}{c}\text { Skull } \\
160689\end{array}$ & $\begin{array}{c}\text { Skull } \\
160990\end{array}$ \\
\hline Shovel shaped & - & Yes \\
4 cusps molars & - & Yes \\
No density & - & Yes \\
Alveolar prognathism face & - & - \\
Small brow ridges & Yes & Yes \\
\hline
\end{tabular}

\begin{tabular}{ccc}
\hline Characteristics of Mongoloid & $\begin{array}{c}\text { Skull } \\
160689\end{array}$ & $\begin{array}{c}\text { Skull } \\
160990\end{array}$ \\
\hline Smooth muscle mark & Yes & Yes \\
Straight post bregma & No & Yes \\
Lower eye border & Yes & Yes \\
Rounded palatal & - & Yes \\
Straight palatal suture & - & Yes \\
Complex cranial suture & Yes & Yes \\
Intermediate nasal aperture & - & Yes \\
Intermediate nasal spine & - & Yes \\
Low and prominent nasal root & Yes & Yes \\
Low nasal bridge & - & Yes \\
Rounded chin & - & - \\
Low and slanted skull shape & Yes & Yes \\
Rounded orbital & Yes & Yes \\
Present of wormian bone & - & Yes \\
Sutura zygomaticomaxillary & No & Yes \\
rectangle shaped & - & - \\
Inion hook & &
\end{tabular}

\section{Stature}

The Measurement of cephalo-facial index was needed to estimate stature, according to the size of skull circumference after the six points had successfully measured. The measurement result was calculated through regression formula by Krishan \& Kumar (2007) (see Table 12).

Table 12. Stature estimation based on cephalo-facial index (on $\mathrm{mm})$ of two skulls

\begin{tabular}{ccccccc}
\hline Skulls & g-op & eu-eu & g-op-g & n-ns & n-pr & apt-apt \\
\hline 160689 & \pm 165 & 145 & 492 & - & - & - \\
160690 & - & 151 & - & 56 & 68 & 26 \\
\hline
\end{tabular}

Table 13 consist of stature estimation data from skull 160689 and 160690 after calculated based on standard error in Table 5. The stature estimation of skull 160689 was between 145-165 cm, while skull 160690 was between $146-168 \mathrm{~cm}$. Based on the result, it indicates both skulls shares similar stature during lifetime.

Table 13. Stature estimation of two skulls

\begin{tabular}{ccc}
\hline Index & Skull 160689 & Skull 160690 \\
\hline g-op & 153,823 & \\
eu-eu & 160,261 & 164,177 \\
g-op-g & 145,519 & - \\
n-ns & - & 160,079 \\
n-pr & - & 156,0608 \\
apt-apt & - & 146,638 \\
Body height & $145-164$ & $146-168$ \\
estimation (cm) & & \\
\hline
\end{tabular}

\section{Individualization}

Individual characteristic had not found on skull 160689 due to its condition. 160689 shows whitish color, which might be the part of taphonomy process. Coloration was caused by particular characteristic which 
initially could be seen macroscopically becoming indistinct. The surface of skull had a rugged texture and some flecks on superior-parietal and lateral side.

Furthermore, another characteristic likely dental modification was appeared as a result of tooth filing. The pattern of dental modification on incisors was hexagonlike shaped frontally, whereas there was a particular treatment on the incisors and canines on lingual side. According to Abdillah et al. (2018) dental modification on skull 160690 had similar modification pattern with skull which found in Kedaton Temple, Trowulan, Mojokerto, East Java. Moreover, dental discoloration marked a black stained on incisors, canines, premolars and molars. The cause of discoloration cannot be recognized whether it happened during lifetime or from
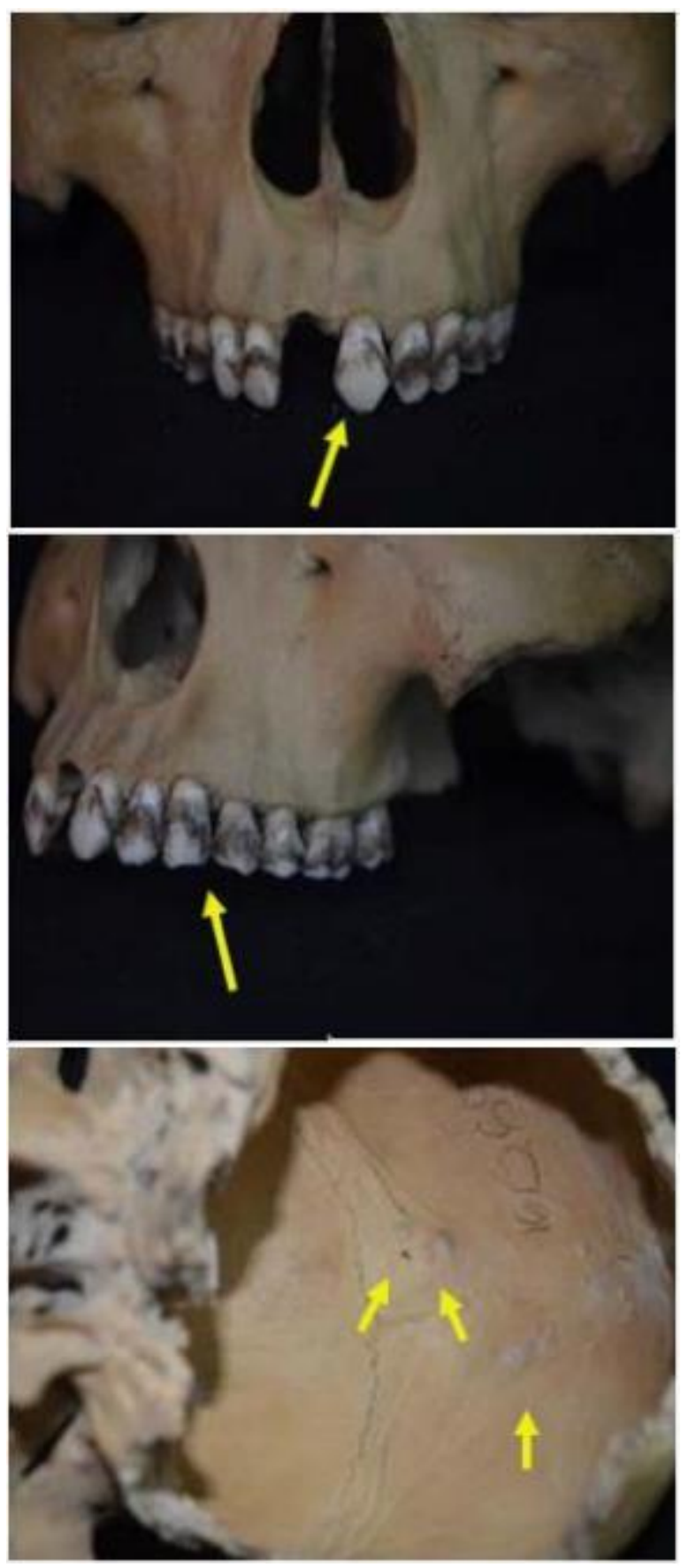

Figure 6. Individual traits on the skull 160690 burial matter. Another characteristic which related with texture and coloration on skull 160690, shows softer trait and tend to yellow color. There were cavities on endocranium as shown in Figure 6.

Overall, generally both skulls showed female characteristics and tended to affiliate to Mongoloid population (Asia). Moreover, by noticing the age and stature indicators, both skulls did not present significant differences for instance, the age difference was about 10 years and the stature estimation was $145-168 \mathrm{~cm}$ (see Table 14).

Table 14. Positive identification results

\begin{tabular}{ccc}
\hline Indicators & Skull 160689 & Skull 160690 \\
\hline Age & $35-45$ & $26-36$ \\
Sex & Female & Female \\
Ancestral group & Mongoloid & Mongoloid \\
Body height & $145-164 \mathrm{~cm}$ & $146-168 \mathrm{~cm}$ \\
\hline
\end{tabular}

According to Widodo (In Soedarso et al., 2013), bunker in Balai Pemuda used for executing the Dutch whom being released from prison. Dutch had most similarity with Caucasoid population. On the other hand, both skulls 160689 and 160690 tended to share similar characteristics with Mongoloid population.

There was an interesting fact on the size of both skulls. Based on superior position, skull 160690 slightly bigger than skull 160689 (see Figure 7), and on vertical position, shape of skull 160689 showed "rhomboids"
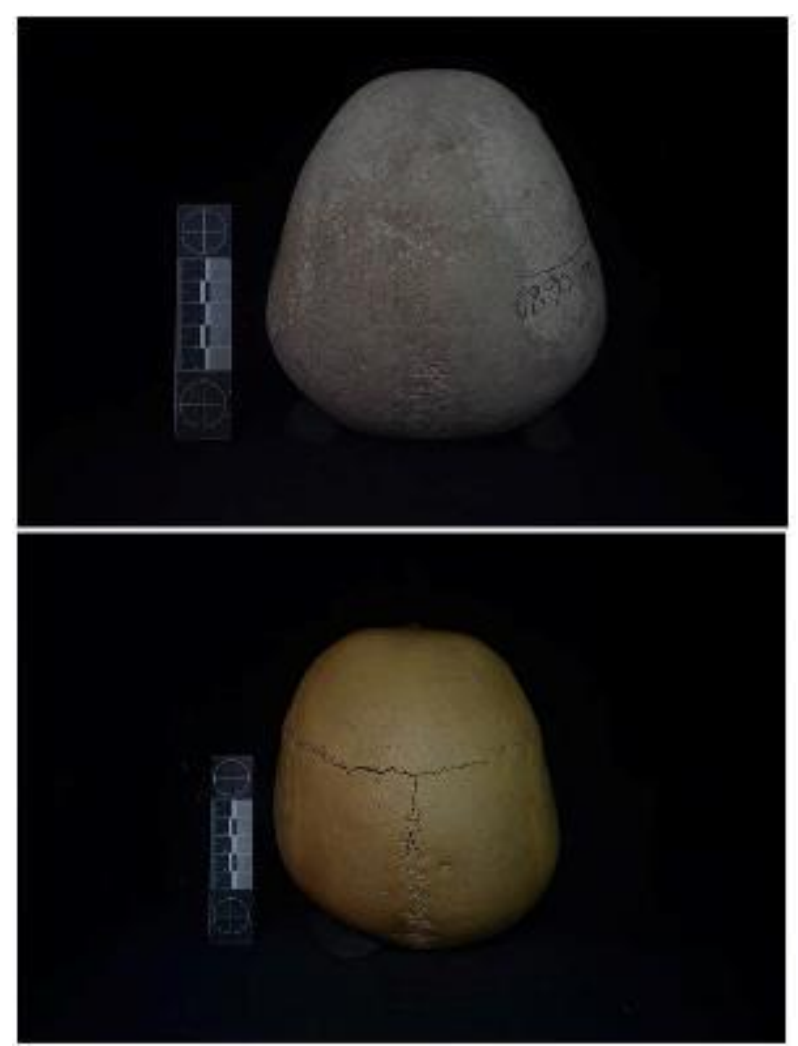

Figure 7. Skull shape comparison of skull 160689 (upper) and 160690 (lower)-min 
trait (triangle-shaped) while skull 160690 tend to showed "spheroids" trait (square-shaped) (Glinka, 1990) (see Figure 8). Skull 160690 could not fully be said as skull with "spheroids" of cranium an enlargement on the occipital that changed the original shape of the skull. Its predicted as skull deformation which caused by particular factors. Brothwell (1981) states that skull deformation is caused by one of the three major factors: pathological condition, pressure of gravitation and artificial deformation.

\section{Pathological condition}

This condition could produce anomaly that might be caused by genetic problems, such as osteogenesis imperfecta or intake troubles like Rickets that might interfere bone growth. The enlargement on occipital from skull 160690 was estimated as pathological
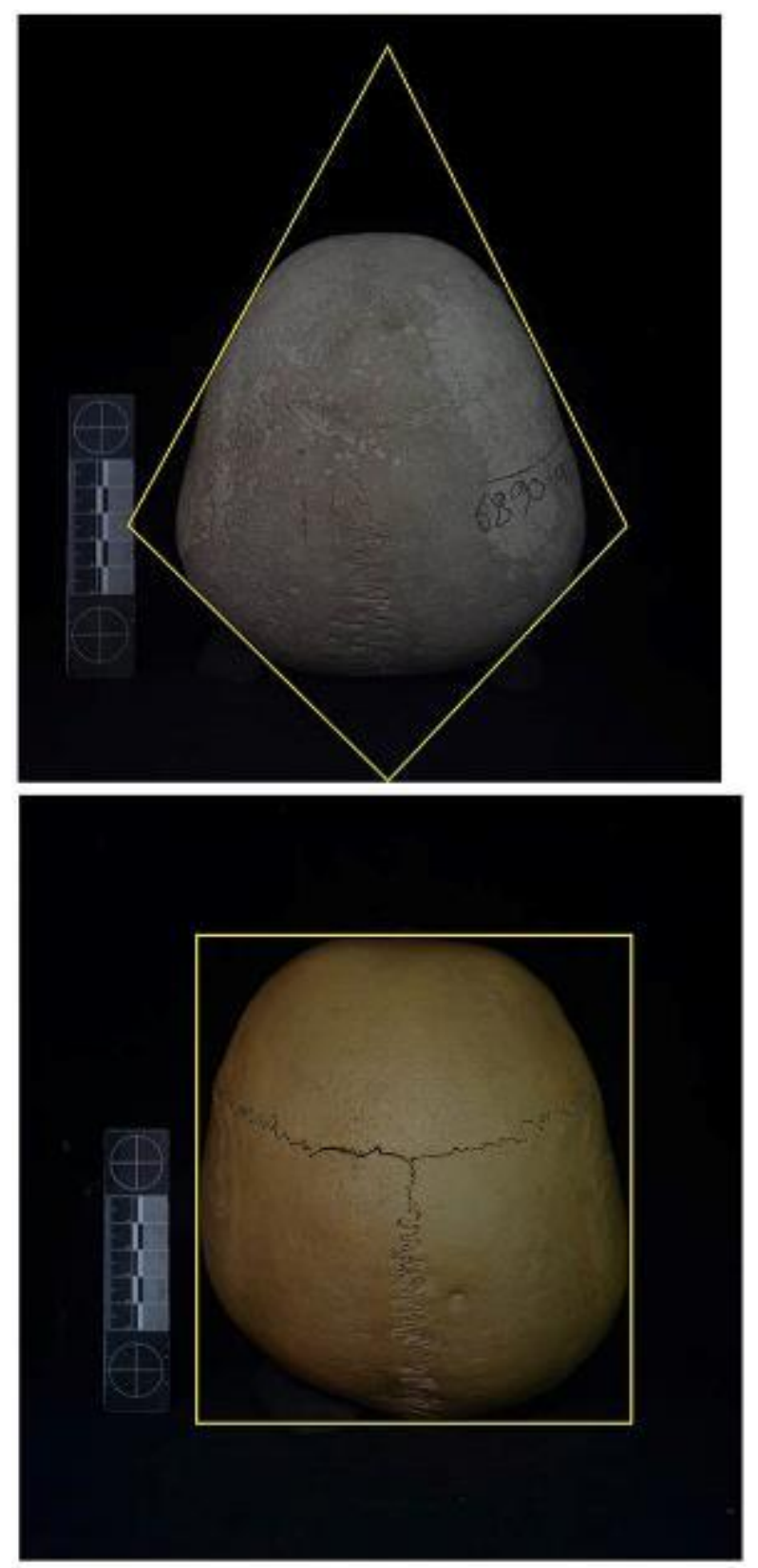

Figure 8. Shape of skull 160689 (upper) and 160690 (lower)-min condition. It was similar with plagiocephaly or flat head syndrome. Plagiocephaly is an asymmetric shape of the cranium with unilateral flattening on the anterior or posterior side of the skull (Pospíšilová \& Procházková, 2006). Moon, Lim, \& Oh (2014) states, asymmetric of the cranium is caused by craniosynostosis or pressure of deformation that happened constantly. As if skull 160690's deformation caused by craniosynostosis, the condition did not appear how it meant to be. Craniosynostosis is an abnormality, where suture tissue forms too early from its standard. It impacts the brain unable to develop maximally due to obstruction of skull development. However, there were no signs of early closure on the skull 160690. Every suture tissue seems normal with no signs of pathological matters.

\section{Pressure of gravitation}

Deformation from the pressure of gravity cannot be separated from soil and climate condition of the site. Several parts of skull that detached on the ground might also cause distortion or deformation. Skull 160690 had connected sutures especially on the neurocranium where presented an asymmetric form. If that asymmetric form caused by the pressure of gravity, then skull 160689 should have had the same matter.

\section{Artificial deformation}

\section{a) Unintentional}

Unintentional artificial deformation is a condition when someone does something on purpose by giving pressure to bones that impact the form of bones. For instance, the use of bandana from ancient Americans caused an unintentional deformation although the deformation is shallow. The condition of Plagiocephaly is expected to appear on the skull 160690.

If plagiocephaly appeared on skull 160690 was caused by the pressure of deformation, it would be categorized as positioning plagiocephaly. This abnormality often occurs in fetuses or born infants. Infant's bones, including skull, has soft characteristic hence deformation could easily appear. The cause might be various, such as a development of obstruction in the uterus or one of the parts of bones that receive pressure continuously (Moon et al., 2014). Cummings (2011) adds the sleep positioning is related to the development of positional plagiocephaly. However, positional plagiocephaly could be controlled/avoided by medical treatment. Based on the analysis, the positional plagiocephaly on skull 160690 happened in childhood. If using a helmet for therapy could prevent the problem, it would not be working on adults, due to the development/maturity issue which starting from age 14 skull is getting hard and the development progress is decline/decrease. 


\section{b) Intentional}

An intentional artificial deformation is a defect that occurred on the human skull for particular purposes to form a specific shape/frame. Usually, this kind of deformation is practiced on infants and juveniles. Romero-Vargas et al. (2010) state, in Ancient Maya a $4-5$ days old baby would be treated by putting 2 boards (front and back area of the skull) so those boards would clamp the skull. This practice would change the shape of frontal bone becoming tilted. Unfortunately, this kind of deformation did not appear on the skull 160689 and 160690. Above all, there is no evidence of skull modification practices in Indonesian cultures.

\section{CONCLUSION}

To conclude, based on the positive identification results on skull 160689 and 160690 showed both skulls were female and affiliated with Mongoloid population. Skull 160689 was estimated between 35-45 years old with 145-164 cm height, while skull 160690 was estimated between $26-36$ years old with $146-168 \mathrm{~cm}$ height.

The distinctive characteristic which found on skull 160689 was whitish color whereas, several unique characteristics were found on skull 169690 , for instance (1) dental modification on incisors and canines with discoloration on aside, (2) endocranial cavity, and (3) deformation on the occipital area. At last, individual characteristic and deformation on the occipital area, were indicated as an unintentional deformation caused by pressure on left side of the occipital area continuously. Plagiocephaly could be a result of incorrect sleeping position during childhood.

\section{ACKNOWLEDGEMENT}

We thank Dr. Ahmad Yudianto, dr. Sp.F, SH, M. Kes. who gave us an opportunity to do a further study on skulls found in Balai Pemuda Surabaya. Also, thank Kapata Arkeologi for publishing this article. We hope this article can provide a scientific impact on science.

\section{REFERENCES}

Abdillah, Y. B., Wisnuyana, B., Mahardika, B. M., Suhendra, Adhinugroho, B., Firdaus, T., ... Koesbardiati, T. (2018). Dental Modification on the Skull Found During Basement Construction at Balai Pemuda Building, Indonesia. Bulletin of the International Association for Paleodontology, 12(2), 47-53.

Brothwell, D. (1981). Digging up Bones: the excavation, treatment, and study of human skeletal remains (3rd ed.). New York: Cornell University Press.

Buikstra, J., \& Ubelaker, D. (1994). Standards for data collection from human skeletal remains: Proceedings of a seminar at the Field Museum of Natural History (Arkansas Archeological Report Research Series). Fayetteville Arkansas Archaeological Survey.

Byers, S. N. (2010). Introduction to Forensic Anthropology (3rd ed.). Boston: Pearson Education.

Cummings, C. (2011). Positional plagiocephaly. Canadian Paediatric Society, 16(8), 493-494.

Ditjen Kebudayaan Kemdikbud. (2019). Balai Pemuda. Retrieved April 20, 2019, from Sistem Registrasi Nasional Cagar Budaya website: http://cagarbudaya.kemdikbud.go.id/cagarbudaya/detail/ PO2016060100001/balai-pemuda

Effendi, Z. (2016, December 2). Dua Tengkorak Manusia Ditemukan di Proyek Basement Balai Pemuda. Detik News. Retrieved from https://news.detik.com/beritajawa-timur/d-3361086/dua-tengkorak-manusiaditemukan-di-proyek-basement-balai-pemuda

Glinka, J. (1990). Antropometri \& Antroposkopi (3rd ed.; N. S. Indrayana, ed.). Surabaya: MEDIPROC.

Koesbardiati, T., \& Murti, D. B. (2016). Sisa Rangka Tentara Jepang dari Perang Dunia II Di Biak. Jurnal Papua, 8(1), 33-43.

Koesbardiati, T., Murti, D. B., \& Putri, R. S. (2018). Petunjuk Identifikasi Rangka Manusia (T. Koesbardiati, Ed.). Surabaya: Direktorat Cakar Budaya dan Museum Kementrian Pendidikan dan Kebudayaan Republik Indonesia.

Krishan, K., \& Kumar, R. (2007). Determination of stature from cephalo-facial dimensions in a North Indian population. Legal Medicine, 9(3), 128-133.

Meindl, R. S., \& Lovejoy, C. O. (1985). Ectocranial Suture Closure: A Revised Method for the Determination of Skeletal Age at Death Based on the Lateral-Anterior Sutures. American Journal Of Physical Anthropology, 68(1), 57-66

Moon, I. Y., Lim, S. Y., \& Oh, K. S. (2014). Analysis of Facial Asymmetry in Deformational Plagiocephaly Using Three-Dimensional Computed Tomographic Review. Archives of Craniofacial Surgery, 15(3), 109-116.

Pospíšilová, B., \& Procházková, O. (2006). Paleopathological Findings Of Dry Skulls With Plagiocephaly. Acta Medica (Hradec Králové), 49(4), 219-226.

Pratama, D. W. (2010). Dari Simpangsche Societeit Hingga Balai Pemuda: Potret Simbol Kekuasaan 1907-1970. Universitas Airlangga.

Riyanto, B. (2000). Iklan Surat Kabar Dan Perubahan Masyarakat Di Jawa Masa Kolonial 1870-1915. Yogyakarta: Terawang.

Romero-Vargas, S., Ruiz-Sandoval, J. L., SotomayorGonzález, A., Revuelta-Gutiérrez, R., Celis-López, M. A., Gómez-Amador, J. L., ... Gómez-Llata, S. (2010). A 
look at Mayan artificial cranial deformation practices: morphological and cultural aspects. Neurosurgical Focus, 29(6), E2

Soedarso, Nurif, M., Sutikno, \& Windiani. (2013). Dinamika Multikultural Masyarakat Kota Surabaya. Jurnal Sosial Humaniora, 6(1), 62-75. 